\title{
Bioaccumulation and effects of sediment-associated gold- and graphene oxide nanoparticles on Tubifex tubifex
}

\author{
Panhong Zhang ${ }^{1,2}$, Henriette Selck ${ }^{3, *}$, Stine Rosendal Tangaa ${ }^{3}$, Chengfang Pang ${ }^{1}$, Bin Zhao ${ }^{1, *}$ \\ 1. State Key Laboratory of Environmental Chemistry and Ecotoxicology, Research Center for Eco-Environmental Sciences, Chinese Academy of \\ Sciences, University of Chinese Academy of Sciences, Beijing 100085, China Email: panhongzhang2015@yeah.net \\ 2. Sino-Danish Center for Education and Research, Beijing 100190, China \\ 3. Department of Science and Environment, Roskilde University, P.O. Box 260, 4000 Roskilde, Denmark
}

\section{A R T I C L E I N F O}

Article history:

Received 5 April 2016

Revised 1 August 2016

Accepted 19 August 2016

Available online 27 September 2016

Keywords:

Metal nanoparticles

Graphene oxide nanoparticles

Burrowing behavior

Benthic invertebrates

Sediment exposure

\begin{abstract}
A B S T R A C T
With the development of nanotechnology, gold (Au) and graphene oxide (GO) nanoparticles have been widely used in various fields, resulting in an increased release of these particles into the environment. The released nanoparticles may eventually accumulate in sediment, causing possible ecotoxicological effects to benthic invertebrates. However, the impact of Au-NPs and GO-NPs on the cosmopolitan oligochaete, Tubifex tubifex, in sediment exposure is not known. Mortality, behavioral impact (GO-NP and Au-NP) and uptake (only Au-NP) of sediment-associated Au-NPs $(4.9 \pm 0.14 \mathrm{~nm})$ and GO-NPs $(116 \pm 0.05 \mathrm{~nm})$ to T. tubifex were assessed in a number of 5-day exposure experiments. The results showed that the applied Au-NP concentrations (10 and $60 \mu \mathrm{g} \mathrm{Au/g}$ dry weight sediment) had no adverse effect on T. tubifex survival, while Au bioaccumulation increased with exposure concentration. In the case of GO-NPs, no mortality of T. tubifex was observed at a concentration range of 20 and $180 \mu \mathrm{g} \mathrm{GO} / \mathrm{g}$ dry weight sediment, whereas burrowing activity was significantly reduced at 20 and $180 \mu \mathrm{g} \mathrm{GO/g}$ dry weight sediment. Our results suggest that Au-NPs at $60 \mu \mathrm{g} \mathrm{Au} / \mathrm{g}$ or GO-NPs at 20 and $180 \mu \mathrm{g} \mathrm{GO/g}$ were detected by T. tubifex as toxicants during short-term exposures. (C) 2016 The Research Center for Eco-Environmental Sciences, Chinese Academy of Sciences.
\end{abstract} Published by Elsevier B.V.

\section{Introduction}

Engineered nanoparticles (ENPs) are widely applied in diverse fields, such as medicine, cosmetics, renewable energy, food industry, electronic devices and environmental remediation (Dong and Feng, 2007; Fabrega et al., 2011; Kachynski et al., 2008; Lens, 2009; Pavasupree et al., 2006; Tungittiplakorn et al., 2004; Wei et al., 2008). Among various engineered nanomaterials, gold ( $\mathrm{Au}$ ) and graphene oxide (GO) nanoparticles are widely used. Both Au-NPs and GO-NPs are unique materials for nano-medicine applications such as drug delivery (Dykman and Khlebtsov, 2012; Zhang et al., 2010) and thermodynamic therapy (Lytton-Jean and Mirkin, 2005;
Wang et al., 2011). Au-NPs have been used in materials science, electron microscopes and biological sensors (Dreaden et al., 2012; Lim et al., 2011; Panyala et al., 2009; Zeng et al., 2011), and GO-NPs have been applied in energy storage, electronics and bioenvironmental materials (Park and Ruoff, 2009; Wang et al., 2011; Zhao et al., 2012). The widespread use of Au-NPs and GO-NPs is likely to increase their release into the aquatic environment via wastewater discharges. Once these nanoparticles are released into the aquatic environment, they will likely undergo transformation processes including dissolution, aggregation, agglomeration, and eventually settle into the sediment (Thit et al., 2015; Zhao et al., 2014). Therefore, sediment may become an ultimate

\footnotetext{
* Corresponding authors. E-mail: selck@ruc.dk (Henriette Selck), binzhao@rcees.ac.cn (Bin Zhao).
} 
reservoir for ENPs. As a result, nanoparticles may be ingested by deposit-feeding benthic invertebrates and potentially be bio-magnified within the food chain (Ferry et al., 2009; Judy et al., 2011), which may pose a high risk to invertebrates and higher trophic level organisms.

Toxicity and bioaccumulation of sediment-associated Ag-NPs and CuO-NPs to sediment-dwelling invertebrates have been investigated (Cong et al., 2011, 2014; Dai et al., 2013; Pang et al., 2012, 2013; Ramskov et al., 2014; Thit et al., 2015). CuO-NPs with concentrations ranging from 30 to $240 \mu \mathrm{g}$ $\mathrm{CuO} / \mathrm{g}$ dry weight sediment negatively affected the specific growth rate, feeding rate, bioaccumulation and reproduction of the freshwater snail Potamopyrgus antipodarum, whereas the survival of P. antipodarum was not affected (Pang et al., 2012, 2013; Ramskov et al., 2014). It was reported that Ag-NPs of 1 to $50 \mu \mathrm{g} \mathrm{Ag/g} \mathrm{dw} \mathrm{sediment} \mathrm{caused} \mathrm{DNA} \mathrm{damage} \mathrm{and} \mathrm{genotoxicity}$ in the marine polychaete Nereis diversicolor (Cong et al., 2014). Furthermore, the burrowing behavior of $\mathrm{N}$. diversicolor was impaired by Ag-NPs at a concentration of $150 \mu \mathrm{g} \mathrm{Ag} / \mathrm{g} \mathrm{dw}$ sediment without affecting survival (Thit et al., 2015). Dai et al. (2013) investigated the toxic effects of sediment-associated Ag-NPs and CuO-NPs on the mussel Macoma balthica and found no negative effects on genotoxicity, mortality, condition index, or burrowing behavior at concentrations from 150 to $200 \mu \mathrm{g} \mathrm{Ag}$ or $\mathrm{CuO} / \mathrm{g}$ dw sediment (Dai et al., 2013).

Studies investigating the toxicity of Au-NPs to organisms have mainly focused on water and soil exposure. Soil exposure showed that Au-NP concentrations up to $37.5 \mu \mathrm{g} \mathrm{Au/g} \mathrm{dw} \mathrm{did}$ not impact the survival and reproduction of the grindal worm Enchytraeus bucchholzi (Voua Otomo et al., 2014). In contrast, Unrine et al. (2010) showed that Au-NPs were accumulated in earthworms (Eisenia fetida) exposed to 5-50 $\mu \mathrm{g} \mathrm{Au/g} \mathrm{dw} \mathrm{soil} \mathrm{and}$ caused adverse effects on reproduction (Unrine et al., 2010). In water exposures, $100 \mu \mathrm{g}$ Au-NP/L induced metallothionein production as a response to metal contamination, and increased activities of catalase, superoxide dismutase and glutathione S-transferase for the bivalve Scrobicularia plana. In addition, the burrowing behavior of S. plana was impaired when transferred from Au contaminated seawater to clean sediment (Pan et al., 2012). GO-NPs have been found to cause negative effects in aquatic invertebrates during development (Mesarič et al., 2013), and induce significant adverse effects on vertebrates, protozoa and microbial communities (Ahmed and Rodrigues, 2013; Chen et al., 2012; Hu et al., 2015). However, few studies have been conducted with sediment.

The sediment-dwelling Oligochaete, Tubifex tubifex was selected as model organism, because they are widely distributed in the freshwater eco-system, and have a feeding behavior that includes ingesting large amounts of fine particles $(<60 \mu \mathrm{m})$ and extract organic matter associated with ingested sediment. Due to their bioturbation activities (i.e., irrigation and particle mixing), high tolerance for polluted ecosystems, intermediate position in the trophic network and the ease of breeding in the laboratory, they are widely used as a standard model organism in ecotoxicological studies (Bouche et al., 2000; Lagauzere et al., 2009; Mosleh et al., 2007). However, due to difficulties in tracing NPs in the sediment compartment, the ecotoxicity of NPs on benthic invertebrates in sediment exposure media is scarce and studies with Au-NPs and GO-NPs have not been reported to our knowledge. In the present study, $\mathrm{Au}-\mathrm{NPs}$ and GO-NPs-induced mortality, avoidance, burrowing behavior and bioaccumulation in T. tubifex are investigated via sediment exposure.

\section{Materials and methods}

\subsection{Animal collection and culturing}

T. tubifex were reared in aquaria added sediment and freshwater with frequent additions of extra food (mortared Tetramin $®$ Tetra, Germany) in the laboratory at Roskilde University. The body length of T. tubifex ranged from 4 to $5 \mathrm{~cm}$. One day before experimental setup, all worms were carefully picked out of the culture and placed in artificial T. tubifex media (see below) to empty their guts overnight. During exposure periods, worms were kept in natural sieved sediment without additional food supply.

\subsection{Synthesis and characterization of nanoparticles}

\subsubsection{Synthesis of graphene oxide nanoparticles}

Graphene oxide nanoparticles (GO-NPs) were synthesized according to the modified Hummers method (Hummers and Offeman, 1958). Graphite flakes (1 g, 99.8\%, Alfa Aesar, China) and $\mathrm{NaCl}$ (35 g, Sinopharm Chemical Reagent Ltd., China) were ground into powder with a mortar and pestle. The powder was dissolved in deionized water (18 MPa, Milli-Q water), the solution filtered with filter paper $(50 \mu \mathrm{m})$ and dried in an oven at $60^{\circ} \mathrm{C}$ for $24 \mathrm{hr}$. Subsequently, the dry graphite was dissolved in $\mathrm{H}_{2} \mathrm{SO}_{4}(23 \mathrm{~mL}$, Sinopharm Chemical Reagent Ltd., China), and $\mathrm{KMnO}_{4}$ ( $3 \mathrm{~g}$, Sinopharm Chemical Reagent Ltd., China) was slowly added. The mixture was stirred for $30 \mathrm{~min}$ at $37^{\circ} \mathrm{C}$, followed by $45 \mathrm{~min}$ stirring at $70^{\circ} \mathrm{C}$. Afterwards, $5 \mathrm{~mL}$ deionized water was added, and the solution was heated and stirred for $10 \mathrm{~min}$ at $70^{\circ} \mathrm{C}$ followed by an addition of $40 \mathrm{~mL}$ water and heating for $15 \mathrm{~min}$ at $100^{\circ} \mathrm{C}$. Finally, deionized water $(140 \mathrm{~mL})$ was added, followed by $\mathrm{H}_{2} \mathrm{O}_{2}(10 \mathrm{~mL}$, $30 \%$, Sinopharm Chemical Reagent Ltd., China) in order to obtain the brownish graphite oxide. The graphite oxide was purified by centrifugation at $8000 \mathrm{r} / \mathrm{min}$ for $5 \mathrm{~min}$, followed by washing with $5 \% \mathrm{HCl}$ and deionized water 6 times, successively. In order to enhance electrostatic repulsion, $\mathrm{NaOH}$ $(1.8 \mathrm{~g})$ and deionized water $(10 \mathrm{~mL})$ were added to the above solution, then left in an oil bath and stirred for $4 \mathrm{hr}$. Afterwards, $\mathrm{pH}$ was adjusted to $<1$ by addition of $\mathrm{HCl}(5 \mathrm{~mL}$, $36 \%$, Sinopharm Chemical Reagent Ltd., China). The solution was centrifuged at $8000 \mathrm{r} / \mathrm{min}$ for $5 \mathrm{~min}$ five times with DI water. Afterwards, the solution was sonicated for $45 \mathrm{~min}$ on ice to obtain GO. Finally, the GO solution was concentrated by centrifugation at $13,000 \mathrm{r} / \mathrm{min}$ for $5 \mathrm{~min}$ to give a final concentration of $2.09 \mathrm{mg} / \mathrm{mL}$.

\subsubsection{Synthesis of gold nanoparticles}

Gold nanoparticles (Au-NPs) were synthesized using citrate reduction of $\mathrm{HAuCl}_{4}$ as described by (Brust et al., 1994, 1995). Briefly, $3 \mathrm{~mL}$ of $10 \mathrm{mmol} / \mathrm{L} \mathrm{HAuCl}_{4}$ (AR, Sinopharm Chemical Reagent Ltd., China), $2 \mathrm{~mL}$ of $38.8 \mathrm{mmol} / \mathrm{L}$ citrate (AR, Sinopharm Chemical Reagent Ltd., China) and $1 \mathrm{~mL}$ of 
0.075 wt.\% $\mathrm{NaBH}_{4}$ (AR, Sinopharm Chemical Reagent Ltd., China) were successively added to $80 \mathrm{~mL}$ deionized water at $1 \mathrm{~min}$ intervals with constant stirring. The mixture was stirred for $15 \mathrm{~min}$ at room temperature to obtain $5 \mathrm{~nm}$ Au-NPs. The theoretical Au-NP concentration was $55 \mu \mathrm{g} / \mathrm{mL}$.

\subsubsection{Characterization of Au-NPs and GO-NPs}

The primary particle size of Au-NPs in MilliQ water was assessed by Transmission Electron Microscopy (TEM) (JEM-1011, Japan) operating at $80 \mathrm{kV}$. The particle size of GO-NPs was examined using Atomic Force Microscopy (AFM) (NanoScope ШA Veeco, USA). Hydrodynamic diameters (in suspension) and Zeta potential of Au-NP and GO-NP suspensions prepared in deionized water were measured by Zetasizer Nano (ZS90Malven, UK).

\subsection{Sediment and T. tubifex media preparation}

Sediment was collected at Munkholmbroen in Holbæk, Denmark, sieved to $<125 \mu \mathrm{m}$ using deionized water and left to settle for two days. The overlying water was carefully removed through a plastic tube and the sediment was frozen at $-20^{\circ} \mathrm{C}$ in order to kill micro- and macro-organisms. Afterwards, the sediment was thawed, washed with T. tubifex media once, left to settle and then overlaying water was removed. The ratio of dry weight to wet weight and organic carbon content in the sediment were measured by first placing the wet sediment in the oven for $24 \mathrm{hr}$ at $105^{\circ} \mathrm{C}$, and then heating the dry sediment for $4 \mathrm{hr}$ at $550^{\circ} \mathrm{C}$. T. tubifex media was prepared with $80 \mathrm{mmol} / \mathrm{L} \mathrm{CaCl} \cdot 2 \mathrm{H}_{2} \mathrm{O}, 20 \mathrm{mmol} / \mathrm{L}$ $\mathrm{MgSO}_{4} \cdot 7 \mathrm{H}_{2} \mathrm{O}, 31 \mathrm{mmol} / \mathrm{L} \mathrm{NaHCO} 3$ and $3 \mathrm{mmol} / \mathrm{L} \mathrm{KCl}$ according to OECD 203, ISO 6341-1982, and then aerated for $48 \mathrm{hr}$ prior to use.

\subsection{Sediment spiking and experimental setup}

Sediment was spiked by adding a known amount of Au-NP stock suspension, GO-NP stock suspension or MilliQ water (controls) to 6 separate glass beakers containing wet sediment, to final nominal concentrations of 10 or $60 \mu \mathrm{g} \mathrm{Au} / \mathrm{g} \mathrm{dw}$ for Au-NPs, and 20 or $180 \mu \mathrm{g} \mathrm{GO/g} \mathrm{dw} \mathrm{for} \mathrm{GO-NPs,} \mathrm{respectively.}$ There is to the best of our knowledge no published information on environmental sediment concentrations of either Au-NP or GO-NP. The concentrations selected is based on published studies on Au-NP (soil: (Unrine et al., 2010; Voua otomo et al., 2014)) and $\mathrm{C}_{60}-\mathrm{NP}$ (sediment: (Van der ploeg et al., 2011)) exposures. Sediments were mixed and covered with Parafilm, then left on a shaking table for $24 \mathrm{hr}$ in order to obtain a homogeneous Au-NP and GO-NP distribution, respectively. Hereafter, spiked sediment was transferred to experimental glass beakers ( 3 replicates for each treatment) and T. tubifex media were gently added. The system was left to settle overnight. Hereafter, T. tubifex media were removed and $40 \mathrm{~mL}$ of fresh T. tubifex media were added before introducing $T$. tubifex to the beakers. Worms (20 or 5) were carefully transferred to each beaker to study the toxicities of sediment-associated Au-NPs and GO-NPs on T. tubifex, respectively. After 5 days sediment exposure, the worms were transferred to clean $\mathrm{T}$. tubifex media and left for $6 \mathrm{hr}$ to empty their gut. The experiment was carried out at $(17 \pm 2)^{\circ} \mathrm{C}$ in a controlled climate room for 5 days. Air was supplied to overlying water from pumps through plastic tubes and pipette tips.

\subsection{Sample analysis}

Au-NP concentrations in the start-sediment were measured by flame atomic absorption spectrometry (FAAS, SpectrAA-220 VARIAN Mulgrave, Australia). Au-NP concentrations in worm tissue were determined by graphite AAS (GTA 120 VARIAN Mulgrave, Australia). Samples were lyophilized at $-50^{\circ} \mathrm{C}$ overnight, weighted and digested in a microwave oven. Samples were heated in a mixture of $\mathrm{HNO}_{3}$ (2.25 mL, 35\%) and $\mathrm{HCl}(0.75 \mathrm{~mL}, 35 \%)$ in the microwave oven at 250, 400, 650 and $250 \mathrm{~W}$ for $6 \mathrm{~min}$ at each step. Afterwards, samples were transferred into a water bath at room temperature and cooled for $30 \mathrm{~min}$. Finally, samples were passed through pre-washed filters (Volume: $35 \%, \mathrm{HNO}_{3}$ :MilliQ water $=1: 1(\mathrm{~V}: \mathrm{V}))$ into $25 \mathrm{~mL}$ volumetric flasks. A series of standard Au solution (0, 5, 10, 20, 40, 60, 80 and $100 \mu \mathrm{g} / \mathrm{L})$ were used for calibration of $\mathrm{Au}$ concentrations.

\subsection{Mortality and avoidance response}

The ability of T. tubifex to avoid sediment spiked with either $\mathrm{Au}-\mathrm{NPs}$ or GO-NPs was tested by recording the number of worms on the surface of the sediment at different time slots (1 hr, $12 \mathrm{hr}, 24 \mathrm{hr}, 48 \mathrm{hr}, 72 \mathrm{hr}, 96 \mathrm{hr}$ and $120 \mathrm{hr}$ ) during 5-day exposure. At the end of exposure (day 5), the dead worms were counted. Mortality was calculated using the ratio as the number of dead worms on day 5 divided by the number of worms initially added.

\subsection{Burrowing behavior}

After 5 days of exposure to GO-NP spiked sediment, worms were transferred to beakers containing $2 \mathrm{~cm}$ uncontaminated natural sediment and $40 \mathrm{~mL}$ T. tubifex media. Burrowing behavior was recorded at $30 \mathrm{~min}, 1 \mathrm{hr}, 2 \mathrm{hr}, 12 \mathrm{hr}$ and $24 \mathrm{hr}$.

\subsection{Statistical analysis}

Data is presented as mean \pm standard deviation (SD) of three replicates except for the data of Au bioaccumulation due to the insufficient biomass of worms. One- and two-way analysis of variance (ANOVA) was employed to detect significant differences among samples. Prior to ANOVA, Levene's Test was used to check homogeneity of variances, and normality of distributions was tested with KolmogorovSmirnov. Data were analyzed using SPSS version 19. Significant difference was accepted at a $p$ value $<0.05$. Mortality data were arcsin transformed prior to statistical analyses.

\section{Results}

\subsection{Characterization of Au-NPs and GO-NPs}

TEM images of Au-NPs showed an average primary particle size of $(4.9 \pm 0.14) \mathrm{nm}$ ( $86 \%$ were between 4 and $6 \mathrm{~nm})$ using Nano measure 1.2 software. The particles were spherical and 
relatively monodisperse and particle size was normally distributed (Fig. 1a, b). AFM images revealed that the particle size of GO-NPs fragments ranged from 1to $350 \mathrm{~nm}$ with the majority being around $150 \mathrm{~nm}$ (Fig. 1c, d). Thus, the thickness of GO-NPs were more than the $0.8 \mathrm{~nm}$ which is the typical thickness of single-layer GO sheets (Schniepp et al., 2006), indicating that the synthesized GO-NPs were multi-layered. The hydrodynamic diameter of $50 \mu \mathrm{g} / \mathrm{mL} \mathrm{Au}-\mathrm{NPs}$ and $200 \mu \mathrm{g} / \mathrm{mL}$ GO-NPs suspensions was $(63 \pm 0.34)$ and $(121 \pm 3) \mathrm{nm}$, respectively. The zeta potentials for Au-NPs and GO-NPs in MilliQ water were $(-34.4 \pm 1.2)$ and $(-60.2 \pm 1.2) \mathrm{mV}$, respectively, indicating that both suspensions were stable.

\subsection{Sediment properties}

The ratio of dry weight to wet weight of sediment was 0.38 , the organic matter content was $0.9 \%$ and the background $\mathrm{Au}$ concentration was lower than the detection limit $(<5 \mu \mathrm{g} \mathrm{Au} / \mathrm{g}$ $\mathrm{dw}$ sediment). The concentration of $\mathrm{Au}$ in Au-NPs spiked sediment $(n=4)$ was $(8.58 \pm 1.55) \mu \mathrm{g} \mathrm{Au} / \mathrm{g}$ and $(70.27 \pm$ 6.70) $\mu \mathrm{g} \mathrm{Au/g} \mathrm{dw,} \mathrm{respectively,} \mathrm{which} \mathrm{was} \mathrm{close} \mathrm{to} \mathrm{the}$ nominal concentrations (i.e., 10 and $60 \mu \mathrm{g} \mathrm{Au} / \mathrm{g} \mathrm{dw}$ ). For GO-NPs, nominal concentrations of $20 \mu \mathrm{g} / \mathrm{g} \mathrm{dw}$ or $180 \mu \mathrm{g} / \mathrm{g}$ $\mathrm{dw}$ were chosen, and 0.47 or $4.26 \mathrm{~mL}$ of the concentration GO-solution was added to the sediment, respectively. The final concentration of GO-NPs in sediment was not determined due to insufficient analysis methods.

\subsection{Effects of Au-NPs to T. tubifex}

\subsubsection{Mortality and avoidance behavior}

The mortality of $\mathrm{T}$. tubifex was $5 \%$ in the control, $3.33 \%$ in $10 \mu \mathrm{g} / \mathrm{g}$ and $11.67 \%$ in $60 \mu \mathrm{g} / \mathrm{g} \mathrm{dw}$. No significant difference in mortality between treatments was observed $(p=0.124)$. During 5 day exposure, T. tubifex exhibited avoidance behavior to sediment treated with the three concentrations of Au-NPs (i.e., 0, 10 or $60 \mu \mathrm{g} / \mathrm{g} \mathrm{dw}$ ) (Fig. 2). Au concentration and exposure duration did not interact to affect the avoiding behavior $(p>0.05)$. However, there was a tendency that high exposure concentration resulted in a stronger avoiding behavior, especially in the beginning of the exposure period (Fig. 2).
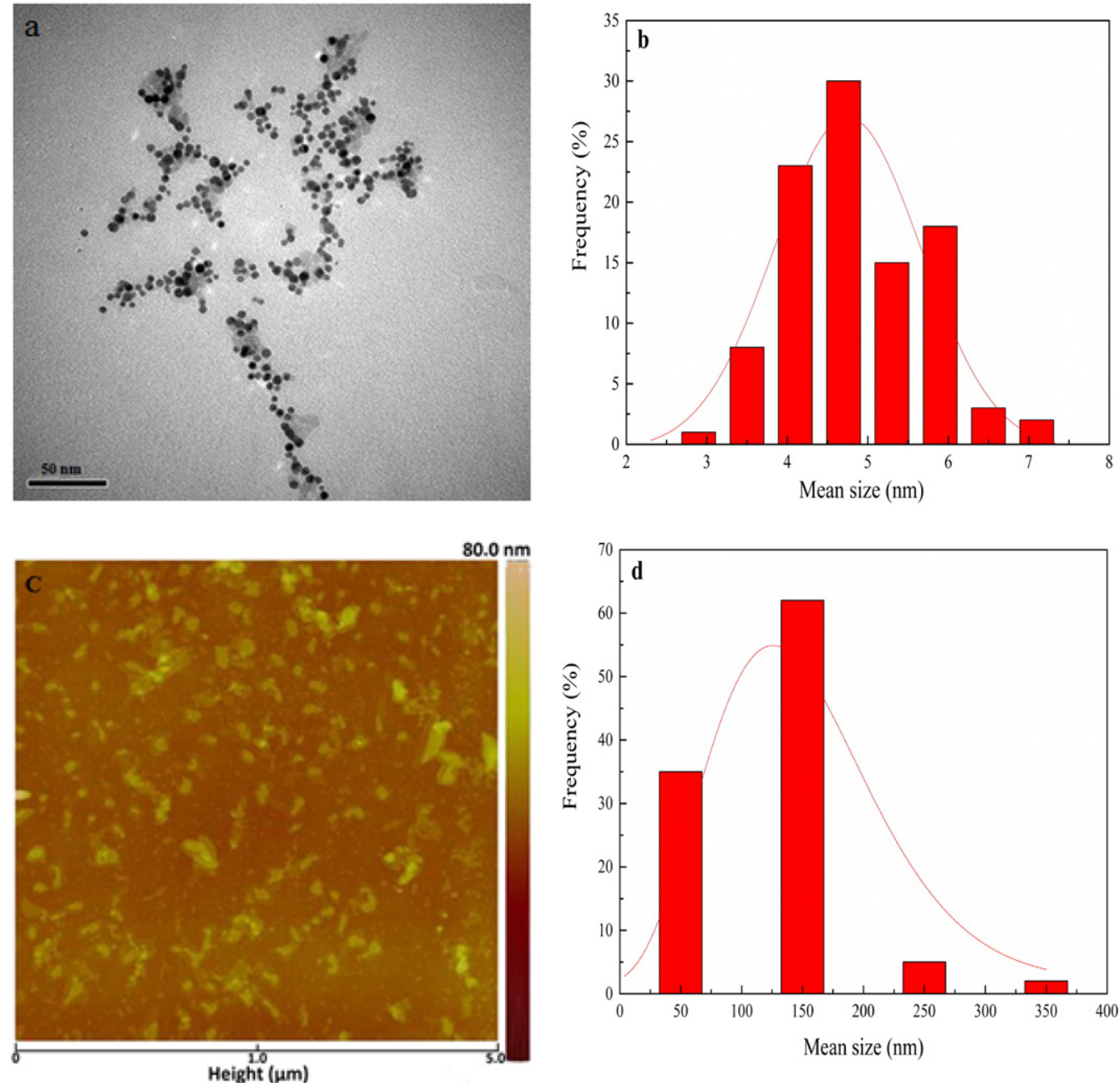

Fig. 1 - Transmission electron microscopy (TEM), atomic force microscopy (AFM) and size distribution of Au-NPs and GO-NPs in MilliQ water: (a) TEM images of $5 \mathrm{~nm} \mathrm{Au-NPs,} \mathrm{(b)} \mathrm{size} \mathrm{distribution} \mathrm{of} \mathrm{Au-NPs,} \mathrm{(c)} \mathrm{AFM} \mathrm{images} \mathrm{of} \mathrm{GO-NPs,} \mathrm{(d)} \mathrm{size} \mathrm{distribution} \mathrm{of}$ GO-NPs. Au: gold; NPs: nanoparticles; GO: graphene oxide. 


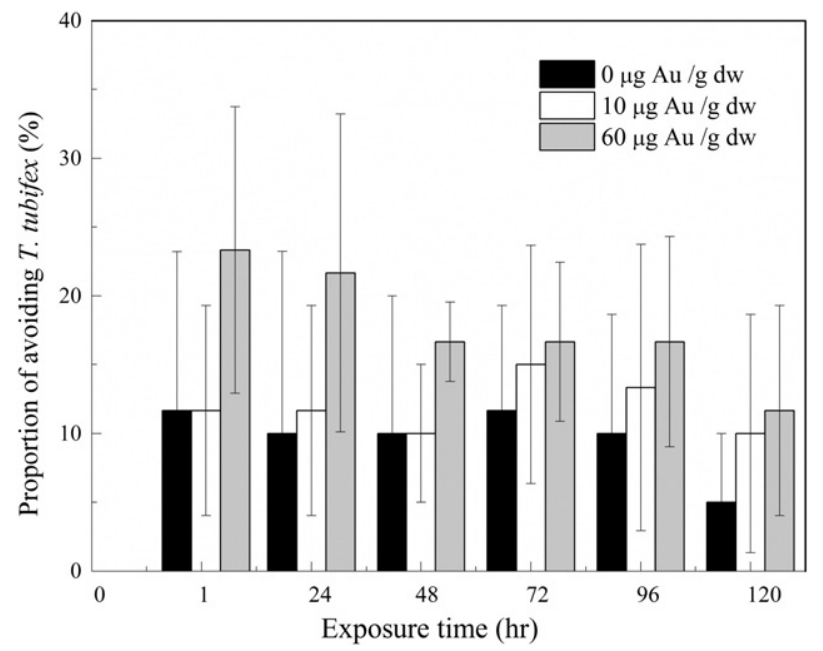

Fig. 2 - Avoidance response of T. tubifex during 5-day sediment exposure with Au-NPs $(n=3)$. The bars represent standard deviation (SD).

\subsubsection{Bioaccumulation of Au-NPs in T. tubifex}

Au accumulated in T. tubifex tissue during the 5-day sediment exposure. In the control group, the Au body burden was lower than the detection limit. The body burdens of Au in T. tubifex after 5 days was 12.49 and $65.84 \mu \mathrm{g} / \mathrm{g}$ dw when exposed to 10 and $60 \mu \mathrm{g} / \mathrm{g} \mathrm{dw}$ sediment, respectively. However, to reach above the detection limit in worm tissue, worm biomass was pooled among three replicates leaving one data point per exposure concentration $(0,10,60 \mu \mathrm{g} \mathrm{AuNP} / \mathrm{g} d w$ sediment, $n=1$ containing up to 20 samples). Thus, no statistical test could be performed, however, the data does show a clear tendency of a concentration-dependent accumulation of $\mathrm{Au}$ in T. tubifex worms.

\subsection{Effect of GO-NPs on T. tubifex}

\subsubsection{Mortality}

No worm mortality was observed after 5-day sediment exposure to 20 and $180 \mu \mathrm{g} \mathrm{GO} / \mathrm{g}$ dw sediment.

\subsubsection{Avoidance and burrowing behavior}

Avoidance. There was no interaction between $\mathrm{Au}$ concentration and exposure duration on avoidance behavior of $\mathrm{T}$. tubifex during 5 days of exposure $(p>0.05)$. During the first hour of exposure to GO-NP spiked sediment, only a few $\mathrm{T}$. tubifex were visible at the sediment surface in the control treatment, while $20 \%$ and $24 \%$ of T. tubifex were observed on the surface of the $20 \mu \mathrm{g} \mathrm{GO} / \mathrm{g}$ dw sediment and $180 \mu \mathrm{g} \mathrm{GO} / \mathrm{g} \mathrm{dw}$ sediment, respectively (Fig. 3). Yet, no significant avoidance was detected among treatments $(p>0.05)$.

Burrowing behavior. After T. tubifex were transferred into clean sediment, time for all organisms to fully burry into the clean sediment was significantly dependent on the pre-exposure concentration, such that time increased with increasing sediment concentration of GO-NPs $(p=0.005)$.
T. tubifex took $1 \mathrm{hr}$ to completely burrow into the sediment in the control treatment, while 8 and $24 \mathrm{hr}$ was needed to completely burrow into the sediment for worms pre-exposed to 20 and $180 \mu \mathrm{g} \mathrm{GO} / \mathrm{g}$ dw, respectively (Fig. 4).

\section{Discussion}

\subsection{Au-NP effects and Au bioaccumulation in T. tubifex}

Generally, sediment-associated Au-NP showed low mortality to T. tubifex. Au-NPs with a concentration of 10 and $60 \mu \mathrm{g} \mathrm{Au} / \mathrm{g}$ $\mathrm{dw}$ had no significant effects on the avoidance behavior of $\mathrm{T}$. tubifex during the short-term exposure. However, there was a tendency for higher avoidance for worms exposed to higher concentration of Au-NP and that the lack of significance may be related to a high variation in data. Avoidance responses induced by metal nanoparticles have not been examined greatly in the aquatic environment. Ramskov et al. (2014) reported an avoidance response of the freshwater snail, $P$. antipodarum, exposed to $100 \mu \mathrm{g} \mathrm{Ag-NPs/g} \mathrm{dw} \mathrm{sediment} \mathrm{for}$ 14 days. An avoidance behavior of the polychaete $\mathrm{N}$. diversicolor was also observed during exposure to $100 \mu \mathrm{g}$ Ag-NP/g dw and $150 \mu \mathrm{g}$ CuO-NP/g dw for 10 days, respectively (Cong et al., 2014; Thit et al., 2015), indicating that benthic invertebrates are able to detect and avoid nanoparticles in sediment exposure, this is in accordance with the present studies on the avoidance behavior of T. tubifex to nanoparticles. Furthermore, studies exist examining soil exposures of Oligochates, such as the earthworms Eisenia fetida and Enchytraeus albidus. E. fetida consistently avoided soil spiked with Ag-NPs in concentrations of 6.97-54 $\mu \mathrm{g} \mathrm{Ag/g} \mathrm{dw,} \mathrm{Al}_{2} \mathrm{O}_{3^{--}}$ NPs with concentrations of $5000-10,000 \mu \mathrm{g} \mathrm{Al} \mathrm{O}_{2} \mathrm{O}_{3} / \mathrm{g} \mathrm{dw}$ and $\mathrm{TiO}_{2}$-NPs with concentrations of $1000-5000 \mu \mathrm{g} \mathrm{TiO} / 2 / g$ dw over $48 \mathrm{hr}$, respectively (Coleman et al., 2010; McShane et al., 2012; Shoults-Wilson et al., 2011). Likewise, E. albidus significantly avoided Cu-NPs with a concentration of 43-241 $\mu \mathrm{g} \mathrm{Cu} / \mathrm{g} d w$ during $48 \mathrm{hr}$ of soil exposure, and the $\mathrm{EC}_{50 \text {-avoidance }}$ was $241 \mu \mathrm{g}$ $\mathrm{Cu} / \mathrm{g} \mathrm{dw}$ (Amorim and Scott-Fordsmand, 2012).

Metal nanoparticle bioaccumulation in benthic invertebrates in sediment exposure has been studied in a number of benthic invertebrates including the clam M. balthica (Dai et al., 2013), the freshwater snail P. antipodarum (Pang et al., 2012, 2013; Ramskov et al., 2014), the estuarine worm H. diversicolor/ N. diversicolor (Buffet et al., 2011, 2014; Cong et al., 2014). In sediment exposure, P. antipodarum accumulated 40-155 $\mu \mathrm{g}$ $\mathrm{Cu} / \mathrm{g} \mathrm{dw}$ after a long term exposure (8 weeks) to 30-240 $\mu \mathrm{g}$ CuO-NPs/g dry weight sediment, and the $\mathrm{Cu}$ body burden increased with increasing exposure concentration (Pang et al., 2012). For Ag-NPs, the clam M. balthica were able to accumulate $200-250 \mu \mathrm{g} \mathrm{Ag} / \mathrm{g}$ dw after 35 days of exposure to $200 \mu \mathrm{g} / \mathrm{g}$ dw sediment spiked with Ag-NPs (20-80 nm) (Dai et al., 2013). Likewise, in a short-term sediment exposure, $N$. diversicolor accumulated approximately 2-9 $\mu \mathrm{g} \mathrm{Ag} / \mathrm{g}$ dw tissue after exposure to Ag-NPs (5-100 $\mu \mathrm{g}$ Ag-NPs/g dw sediment), and accumulated Ag increased with exposure concentrations (Cong et al., 2014). These results suggested that benthic invertebrates could accumulate nanoparticles like CuO-NP and Ag-NP. There exist to our knowledge no reported Au bioaccumulation data following sediment-exposure to $\mathrm{Au}$ 


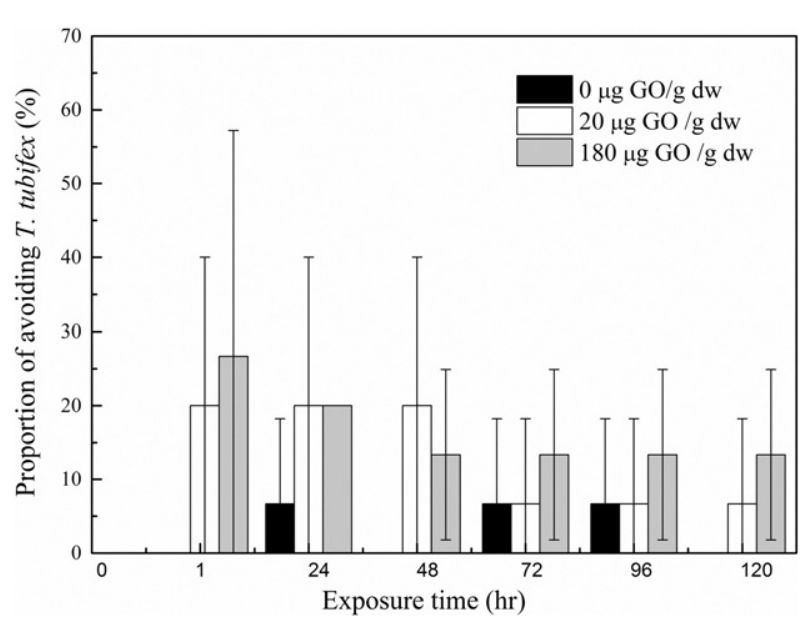

Fig. 3 - Avoidance response of T. tubifex during 5-day sediment exposure with GO $(n=3)$. The bars represent standard deviation (SD).

NPs, but results are available for Tellinid clams and earthworms following water and soil exposures, respectively. The clam S. plana accumulated $\mathrm{Au}$ in their soft tissues and the mean concentrations reaching 10.5, 12.0 and $17.7 \mu \mathrm{g} \mathrm{Au} / \mathrm{g}$, respectively for S. plana exposed to $100 \mu \mathrm{g} / \mathrm{L}$ of Au-NPs with the size of 5, 15 and $40 \mathrm{~nm}$ for 16 days (Pan et al., 2012). The earthworm E. fetida, accumulated 0.3-1.5 $\mu \mathrm{g} \mathrm{Au/g}$ fresh tissue after 28 days of exposure to $10 \mu \mathrm{g} \mathrm{Au} / \mathrm{g} d w$ of Au-NPs, and Au bioaccumulation followed in a dose-dependent manner (Unrine et al., 2010). In the present study, there was a tendency that bioaccumulation of Au-NPs in T. tubifex increased with increasing exposure concentration, and bioaccumulated $\mathrm{Au}$ in T. tubifex was up to $65.84 \mu \mathrm{g} \mathrm{Au} / \mathrm{g}$ following exposure to $60 \mu \mathrm{g} \mathrm{Au} / \mathrm{g}$ dw sediment of Au-NPs in

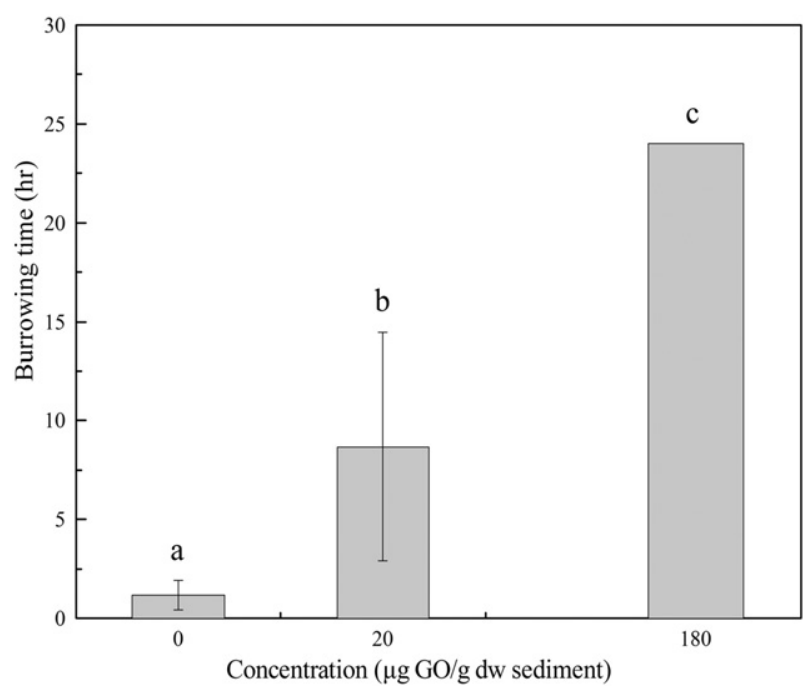

Fig. 4 - Time for all T. tubifex in each beaker to completely burrow in clean natural sediment after 5-day exposure to GO-NPs. The bars represent standard deviation (SD) $(n=3)$. Different letters indicate statistical differences at $p<0.05$ level. a short term period (5 days). Thus, there exist data indicating that benthic invertebrates are able to accumulate CuO-NP, Ag-NP as well as Au-NP on sediment exposure.

\subsection{Impaired burrowing behavior of $\mathrm{T}$. tubifex following exposure to sediment-associated GO-NPs}

The GO-NPs with a concentration of 20 and $180 \mu \mathrm{g} \mathrm{GO} / \mathrm{g}$ dw in the sediment did not affect the survival of $T$. tubifex following 5-day exposure in this study. This is in accordance with earlier published results showing low or no mortality in organisms exposed to other carbon nanomaterials (Liu et al., 2014; Pakarinen et al., 2011; Petersen et al., 2008). For example, the mortality of the Oligochate Lumbriculus variegatus was not affected by exposure (28 days) to $50 \mu \mathrm{g}$ fullerenes $/ g$ dw sediment, $0.03 \mu \mathrm{g}$ SWCNT (single-wall carbon nanotubes)/g dw sediment (SWCNT) or $0.03 \mu \mathrm{g}$ MWCNT (multi-wall carbon nanotubes)/g dw sediment (Pakarinen et al., 2011; Petersen et al., 2008). GO-NPs has also showed low mortality in other test systems like water exposure, where Liu et al. (2014) reported that 1-100 $\mathrm{mg} \mathrm{GO} / \mathrm{L}$ had no adverse effects on the survival of zebrafish embryos after 96 hr exposure (Liu et al., 2014).

The burrowing behavior of T. tubifex in clean sediment was significantly affected following exposure to 20 and $180 \mu \mathrm{g} \mathrm{GO} / \mathrm{g}$ $\mathrm{dw}$ in the present study. Similar observations were reported for N. diversicolor, and S. plana exposed to different nanoparticles such as CuO-NP, Ag-NP, CdS-NP and ZnO-NP (Cong et al., 2014; Boldina-Cosqueric et al., 2010; Buffet et al., 2012, 2013a, 2013b, 2014; Thit et al., 2015). Boldina-Cosqueric et al. (2010) discussed the origins of impairments of burrowing behavior in S. plana. They found that the reduced burrowing speed of clams from a clean site exposed to contaminated sediment may be interpreted as an avoidance response (Boldina-Cosqueric et al., 2010), In addition, the burrowing behavior was significantly decreased for worms (H. diversicolor) exposed to $10 \mu \mathrm{g} \mathrm{Cu} / \mathrm{L}$ of CuO NP for 14 days (Buffet et al., 2013a), suggesting that burrowing behavior of benthic invertebrates may be a more sensitive endpoint in behavior tests, and likely of particularly importance when considering NP effects. Since T. tubifex plays an important role in biogeochemical processes through its burrowing and irrigation activity, the impairment of burrowing behavior may lead to ecologically detrimental effects, such as an increase in the susceptibility of sediment-dwelling species to predation. This could lead to an increased predation of contaminated worms by fish, possibly biomagnifying NPs up the food chain, thereby affecting the entire ecosystem. However, the concentration range from 20 to $180 \mu \mathrm{g}$ GO-NPs/g dw used in this study is not expected in the environment, making considerations like this predominantly theoretical.

\section{Acknowledgments}

This work was conducted at Roskilde University, Denmark. The authors thank Prof. Bing Yan from Shandong University for technical assistance to synthesis of Au-NPs and GO-NPs. This study was supported by the National Natural Science Foundation of China (Nos. 21525730, 21407162), the Strategic Priority Research Program of the Chinese Academy of Sciences (Nos. XDB14030401, XDB14030402), Roskilde University, 
and Sino-Danish Center for Education and Research Center. We would like to thank Dr. Marjie Philips from the University of California, Davis for her critical comments during the preparation of this paper, also we are really grateful to Amalie Thit Jensen for advisory assistance to the experimental setup, and to Mette Flodgaard and Cong Li for laboratory assistance. And thanks to Ronja Windfeld for providing the test organisms T. tubifex.

\section{R E F E R E N C E S}

Ahmed, F., Rodrigues, D.F., 2013. Investigation of acute effects of graphene oxide on wastewater microbial community: a case study. J. Hazard. Mater. 256, 33-39.

Amorim, M.J.B., Scott-Fordsmand, J.J., 2012. Toxicity of copper nanoparticles and $\mathrm{CuCl}_{2}$ salt to Enchytraeus albidus worms: survival, reproduction and avoidance responses. Environ. Pollut. 164, 164-168.

Boldina-Cosqueric, I., Amiard, J.C., Amiard-Triquet, C., Dedourge-Geffard, O., Metais, I., Mouneyrac, C., 2010. Biochemical, physiological and behavioural markers in the endobenthic bivalve Scrobicularia plana as tools for the assessment of estuarine sediment quality. Ecotoxicol. Environ. Saf. 73 (7), 1733-1741.

Bouche, M.L., Habets, F., Biagianti-Risbourg, S., Vernet, G., 2000. Toxic effects and bioaccumulation of cadmium in the aquatic oligochaete Tubifex tubifex. Ecotoxicol. Environ. Saf. 46 (3), 246-251.

Brust, M., Walker, M., Bethell, D., Schiffrin, D.J., Whyman, R., 1994. Synthesis of thiol-derivatised gold nanoparticles in a two-phase liquid-liquid system. J. Chem. Soc. Chem. Commun. 7, 801-802.

Brust, M., Fink, J., Bethell, D., Schiffrin, D., Kiely, C., 1995. Synthesis and reactions of functionalised gold nanoparticles. J. Chem. Soc. Chem. Commun. 16, 1655-1656.

Buffet, P.E., Tankoua, O.F., Pan, J.F., Berhanu, D., Herrenknecht, C., Poirier, L., et al., 2011. Behavioural and biochemical responses of two marine invertebrates Scrobicularia plana and Hediste diversicolor to copper oxide nanoparticles. Chemosphere 84 (1), 166-174.

Buffet, P.E., Amiard-Triquet, C., Dybowska, A., Risso-de Faverney, C., Guibbolini, M., Valsami-Jones, E., et al., 2012. Fate of isotopically labeled zinc oxide nanoparticles in sediment and effects on two endobenthic species, the clam Scrobicularia plana and the ragworm Hediste diversicolor. Ecotoxicol. Environ. Saf. 84, 191-198.

Buffet, P.E., Richard, M., Caupos, F., Vergnoux, A., Perrein-Ettajani, H., Luna-Acosta, A., et al., 2013a. A mesocosm study of fate and effects of $\mathrm{CuO}$ nanoparticles on endobenthic species (Scrobicularia plana, Hediste diversicolor). Environ. Sci. Technol. 47 (3), 1620-1628.

Buffet, P.E., Pan, J.F., Poirier, L., Amiard-Triquet, C., Amiard, J.C., Gaudin, P., et al., 2013b. Biochemical and behavioural responses of the endobenthic bivalve Scrobicularia plana to silver nanoparticles in seawater and microalgal food. Ecotoxicol. Environ. Saf. 89, 117-124.

Buffet, P.E., Poirier, L., Zalouk-Vergnoux, A., Lopes, C., Amiard, J.C., Gaudin, P., et al., 2014. Biochemical and behavioural responses of the marine polychaete Hediste diversicolor to cadmium sulfide quantum dots (CdS QDs): waterborne and dietary exposure. Chemosphere 100, 63-70.

Chen, L., Hu, P., Zhang, L., Huang, S., Luo, L., Huang, C., 2012. Toxicity of graphene oxide and multi-walled carbon nanotubes against human cells and zebrafish. Sci. China: Chem. 55 (10), 2209-2216.

Coleman, J.G., Johnson, D.R., Stanley, J.K., Bednar, A.J., Weiss, C.A., Boyd, R.E., et al., 2010. Assessing the fate and effects of nano aluminum oxide in the terrestrial earthworm, Eisenia fetida. Environ. Toxicol. Chem. 29 (7), 1575-1580.

Cong, Y., Banta, G.T., Selck, H., Berhanu, D., Valsami-Jones, E., Forbes, V.E., 2011. Toxic effects and bioaccumulation of nano-, micron- and ionic-Ag in the polychaete, Nereis diversicolor. Aquat. Toxicol. 105 (3), 403-411.

Cong, Y., Banta, G.T., Selck, H., Berhanu, D., Valsami-Jones, E., Forbes, V.E., 2014. Toxicity and bioaccumulation of sedimentassociated silver nanoparticles in the estuarine polychaete, Nereis (Hediste) diversicolor. Aquat. Toxicol. 156, 106-115.

Dai, L., Syberg, K., Banta, G.T., Selck, H., Forbes, V.E., 2013. Effects, uptake, and depuration kinetics of silver oxide and copper oxide nanoparticles in a marine deposit feeder, Macoma balthica. ACS Sustain. Chem. Eng. 1 (7), 760-767.

Dong, Y., Feng, S.S., 2007. In vitro and in vivo evaluation of methoxy polyethylene glycol-polylactide (MPEG-PLA) nanoparticles for small-molecule drug chemotherapy. Biomaterials 28 (28), 4154-4160.

Dreaden, E.C., Alkilany, A.M., Huang, X., Murphy, C.J., El-Sayed, M.A., 2012. The golden age: gold nanoparticles for biomedicine. Chem. Soc. Rev. 41 (7), 2740-2779.

Dykman, L., Khlebtsov, N., 2012. Gold nanoparticles in biomedical applications: recent advances and perspectives. Chem. Soc. Rev. 41 (6), 2256-2282.

Fabrega, J., Luoma, S.N., Tyler, C.R., Galloway, T.S., Lead, J.R., 2011. Silver nanoparticles: behaviour and effects in the aquatic environment. Environ. Int. 37 (2), 517-531.

Ferry, J.L., Craig, P., Hexel, C., Sisco, P., Frey, R., Pennington, P.L., et al., 2009. Transfer of gold nanoparticles from the water column to the estuarine food web. Nat. Nanotechnol. 4 (7), 441-444.

Hu, C., Wang, Q., Zhao, H., Wang, L., Guo, S., Li, X., 2015. Ecotoxicological effects of graphene oxide on the protozoan Euglena gracilis. Chemosphere 128, 184-190.

Hummers Jr., W.S., Offeman, R.E., 1958. Preparation of graphitic oxide. J. Am. Chem. Soc. 80 (6), 1339-1339.

Judy, J.D., Unrine, J.M., Bertsch, P.M., 2011. Evidence for biomagnification of gold nanoparticles within a terrestrial food chain. Environ. Sci. Technol. 45 (2), 776-781.

Kachynski, A.V., Kuzmin, A.N., Nyk, M., Roy, I., Prasad, P.N., 2008. Zinc oxide nanocrystals for nonresonant nonlinear optical microscopy in biology and medicine. J. Phys. Chem. C 112 (29), 10721-10724.

Lagauzere, S., Terrail, R., Bonzom, J.M., 2009. Ecotoxicity of uranium to Tubifex tubifex worms (Annelida, Clitellata, Tubificidae) exposed to contaminated sediment. Ecotoxicol. Environ. Saf. 72 (2), 527-537.

Lens, M., 2009. Use of fullerenes in cosmetics. Recent Pat. Biotechnol. 3 (2), 118-123.

Lim, Z.Z.J., Li, J.E.J., Ng, C.T., Yung, L.Y.L., Bay, B.H., 2011. Gold nanoparticles in cancer therapy. Acta Pharmacol. Sin. 32 (8), 983-990.

Liu, X.T., Mu, X.Y., Wu, X.L., Meng, L.X., Guan, W.B., Ma, Y.Q., et al., 2014. Toxicity of multi-walled carbon nanotubes, graphene oxide, and reduced graphene oxide to zebrafish embryos. Biomed. Environ. Sci. 27 (9), 676-683.

Lytton-Jean, A.K., Mirkin, C.A., 2005. A thermodynamic investigation into the binding properties of DNA functionalized gold nanoparticle probes and molecular fluorophore probes. J. Am. Chem. Soc. 127 (37), 12754-12755.

McShane, H., Sarrazin, M., Whalen, J.K., Hendershot, W.H., Sunahara, G.I., 2012. Reproductive and behavioral responses of earthworms exposed to nano-sized titanium dioxide in soil. Environ. Toxicol. Chem. 31 (1), 184-193.

Mesarič, T., Sepčič, K., Piazza, V., Gambardella, C., Garaventa, F., Drobne, D., et al., 2013. Effects of nano carbon black and single-layer graphene oxide on settlement, survival and swimming behaviour of Amphibalanus amphitrite larvae. Chem. Ecol. 29 (7), 643-652.

Mosleh, Y.Y., Paris-Palacios, S., Ahmed, M.T., Mahmoud, F.M., Osman, M.A., Biagianti-Risbourg, S., 2007. Effects of chitosan 
on oxidative stress and metallothioneins in aquatic worm Tubifex tubifex (Oligochaeta, Tubificidae). Chemosphere 67 (1), 167-175.

Pakarinen, K., Petersen, E.J., Leppanen, M.T., Akkanen, J., Kukkonen, J.V., 2011. Adverse effects of fullerenes (nC60) spiked to sediments on Lumbriculus variegatus (Oligochaeta). Environ. Pollut. 159 (12), 3750-3756.

Pan, J.F., Buffet, P.E., Poirier, L., Amiard-Triquet, C., Gilliland, D., Joubert, Y., et al., 2012. Size dependent bioaccumulation and ecotoxicity of gold nanoparticles in an endobenthic invertebrate: the Tellinid clam Scrobicularia plana. Environ. Pollut. 168, 37-43.

Pang, C., Selck, H., Misra, S.K., Berhanu, D., Dybowska, A., ValsamiJones, E., et al., 2012. Effects of sediment-associated copper to the deposit-feeding snail, Potamopyrgus antipodarum: a comparison of $\mathrm{Cu}$ added in aqueous form or as nano- and micro-CuO particles. Aquat. Toxicol. 106, 114-122.

Pang, C., Selck, H., Banta, G.T., Misra, S.K., Berhanu, D., Dybowska, A., et al., 2013. Bioaccumulation, toxicokinetics, and effects of copper from sediment spiked with aqueous $\mathrm{Cu}$, nano-CuO, or micro-CuO in the deposit-feeding snail, Potamopyrgus antipodarum. Ecotoxicol. Environ. Saf. 32 (7), 1561-1573.

Panyala, N.R., Peña-Méndez, E.M., Josef, H., 2009. Gold and nanogold in medicine: overview, toxicology and perspectives. J. Appl. Biomed. 7 (2), 75-91.

Park, S., Ruoff, R.S., 2009. Chemical methods for the production of graphenes. Nat. Nanotechnol. 4 (4), 217-224.

Pavasupree, S., Ngamsinlapasathian, S., Nakajima, M., Suzuki, Y., Yoshikawa, S., 2006. Synthesis, characterization, photocatalytic activity and dye-sensitized solar cell performance of nanorods/nanoparticles $\mathrm{TiO}_{2}$ with mesoporous structure. J. Photochem. Photobiol. A Chem. 184 (1-2), 163-169.

Petersen, E.J., Huang, Q., Weber, W., 2008. Ecological uptake and depuration of carbon nanotubes by Lumbriculus variegatus. Environ. Health Perspect. 116 (4), 496.

Ramskov, T., Selck, H., Banta, G., Misra, S.K., Berhanu, D., ValsamiJones, E., et al., 2014. Bioaccumulation and effects of differentshaped copper oxide nanoparticles in the deposit-feeding snail Potamopyrgus antipodarum. Environ. Toxicol. Chem. 33 (9), 1976-1987.

Schniepp, H.C., Li, J.L., McAllister, M.J., Sai, H., Herrera-Alonso, M., Adamson, D.H., et al., 2006. Functionalized single graphene sheets derived from splitting graphite oxide. J. Phys. Chem. B 110 (17), 8535-8539.
Shoults-Wilson, W., Zhurbich, O.I., McNear, D.H., Tsyusko, O.V., Bertsch, P.M., Unrine, J.M., 2011. Evidence for avoidance of Ag nanoparticles by earthworms (Eisenia fetida). Ecotoxicology 20 (2), 385-396.

Thit, A., Banta, G.T., Selck, H., 2015. Bioaccumulation, subcellular distribution and toxicity of sediment-associated copper in the ragworm Nereis diversicolor: the relative importance of aqueous copper, copper oxide nanoparticles and microparticles. Environ. Pollut. 202, 50-57.

Tungittiplakorn, W., Lion, L.W., Cohen, C., Kim, J.Y., 2004. Engineered polymeric nanoparticles for soil remediation. Environ. Sci. Technol. 38 (5), 1605-1610.

Unrine, J.M., Hunyadi, S.E., Tsyusko, O.V., Rao, W., ShoultsWilson, W.A., Bertsch, P.M., 2010. Evidence for bioavailability of Au nanoparticles from soil and biodistribution within earthworms (Eisenia fetida). Environ. Sci. Technol. 44 (21) 8308-8313.

Van der Ploeg, M.J., Baveco, J.M., Van der Hout, A., Bakker, R., Rietjens, I.M., Van den Brink, N.W., 2011. Effects of C60 nanoparticle exposure on earthworms (Lumbricus rubellus) and implications for population dynamics. Environ. Pollut. 159 (1), 198-203.

Voua Otomo, P., Wepener, V., Maboeta, M.S., 2014. Single and mixture toxicity of gold nanoparticles and gold(III) to Enchytraeus buchholzi (Oligochaeta). Appl. Soil Ecol. 84, 231-234.

Wang, Y., Li, Z., Wang, J., Li, J., Lin, Y., 2011. Graphene and graphene oxide: biofunctionalization and applications in biotechnology. Trends Biotechnol. 29 (5), 205-212.

Wei, D., Unalan, H.E., Han, D., Zhang, Q., Niu, L., Amaratunga, G., et al., 2008. A solid-state dye-sensitized solar cell based on a novel ionic liquid gel and $\mathrm{ZnO}$ nanoparticles on a flexible polymer substrate. Nanotechnology 19 (42), 424006.

Zeng, S., Yong, K.T., Roy, I., Dinh, X.Q., Yu, X., Luan, F., 2011. A review on functionalized gold nanoparticles for biosensing applications. Plasmonics 6 (3), 491-506.

Zhang, L., Xia, J., Zhao, Q., Liu, L., Zhang, Z., 2010. Functional graphene oxide as a nanocarrier for controlled loading and targeted delivery of mixed anticancer drugs. Small 6 (4), 537-544.

Zhao, G., Wen, T., Chen, C., Wang, X., 2012. Synthesis of graphenebased nanomaterials and their application in energy-related and environmental-related areas. RSC Adv. 2 (25), 9286-9303.

Zhao, J., Wang, Z., White, J.C., Xing, B., 2014. Graphene in the aquatic environment: adsorption, dispersion, toxicity and transformation. Environ. Sci. Technol. 48 (17), 9995-10009. 